\title{
Research and Practice of Teaching Management Informationization of Colleges and Universities
}

\author{
Xiuying Li \\ Information technology teaching and Management Center \\ Jilin Agricultural University \\ Changchun,,China \\ 729738677@qq.com \\ $+8615604305161$
}

\author{
Dongju Du \\ College Animal Science and Technology \\ Jilin Agricultural University \\ Changchun,,China \\ lxy@jlau.edu.cn
}

\begin{abstract}
Teaching management information is an important way to improve the efficiency of the school, is the core of the modern university development work. With the establishment of the rapid development of computer network technology and the campus network, teaching management information already in practice and will further play a huge role and performance. In this paper, the crux of the necessity of teaching management information, the status of university teaching management and information technology issues, measures tripartite teaching management information construction in the face of college teaching management information necessary to conduct a detailed explanation and discussion.
\end{abstract}

Keywords- information technology; universities; teaching management; Information Technology

\section{INTRODUCTION}

Trend in the world of information technology is the development of the country is the trend of social development, the level of information is a measure of a country's modernization level and an important indicator of overall national strength. Educational information is an important basis for national social informatization construction. Today, IT has become the commanding heights of education reform and development and a breakthrough, education, information technology has become a key factor in achieving the modernization of education and achieve educational innovation, to achieve leapfrog development of education. Teaching is central to the management of school management. Teaching management information is the only way to reform the current management of university teaching and development.

\section{THE CONSTRUCTION OF UNIVERSITY TEACHING} MANAGEMENT INFORMATION IS A NECESSARY REQUIREMENT FOR INFORMATION TECHNOLOGY IN EDUCATION

Education information is the information society to the urgent requirements of higher education, but also the inevitable choice to modernize higher education, bringing both opportunities and challenges for the construction of university teaching management information.

\section{A. achieve the teaching management information data}

Higher education management information to speed up the construction of the school is to adapt the size of college continues to expand, manage the increasingly complex needs. From the provincial Education Examination Yuan to university academic departments are used to modern information technology based management platform to achieve the consistency of student information to facilitate the enrollment management at universities[1]. Teaching management information enables unified data storage standards, data extraction, modify, query more efficient and accurate.

B. promote the standardization of teaching management process

Teaching management information to achieve a uniform standard data storage, data processing method unified, unified data query, data printing formats unity to achieve standardization of teaching management, to avoid the traditional teaching management randomness to ensure the orderly teaching, stable and efficient operation, the full realization of the functions of teaching management, teaching workers to reduce labor intensity and improve their quality of managers, to speed up the process of modernization of education management.

\section{Achieve resource sharing of teaching management}

Academic departments have associated with the students the most authoritative and timeliness of data, which is the basis of the data of various departments. School administration, teachers and students, and other people have different levels of data requirements, which can be through teaching management information platform for sharing resources to varying degrees[2]. Object teaching management information systems in addition to students and teachers, as well as teaching resources, information, etc., involved in all aspects of teaching and learning activities, such as curriculum resources, quality courses through teaching management information platform to achieve resource sharing 


\section{STATUS AND THE CRUX OF THE PROBLEM}

\section{A. Situation of College Teaching Management of information technology.}

Looking at the current situation of the overall management of teaching, advanced campus network and IT did not play its due role in teaching management work. Originally campus network can make use of advanced information technology and advanced teaching management in a very short time to complete the work, but because of work followed behind with the means and less effective, resulting in a waste of human and material resources and loss of efficiency. Visible, and face the reality of the existence of objective analysis, give full play to the role of modern information technology equipment, improved information collection, transmission and processing efficiency, improved teaching management information lags behind the situation of information technology in education, improve school teaching management level, is urgent need to address the problem.

\section{B. Management of Information Technology Teaching lag reasons.}

The importance of one pair of teaching management information and urgency of understanding is not enough. Teaching management information is the information management work as a teaching basic elements, and extensive use of information technology in teaching management in various fields to promote the teaching management modernization process[3]. Teaching management information process, should attach great importance to teaching management information in order to view information analysis, and effective use of information technology in teaching management work on this basis. Only information technology to achieve truly modern teaching management, in order to bring bright prospects for teaching management reform and development; are only teaching management to achieve a modern, in order to meet the development needs of today's science and technology in education, in order to more effectively promote the development of information technology in education, in order to better cultivate innovative talents for college.

Lack of investment funds. Information requires a solid infrastructure. So far, China has not yet completed the process of industrialization, between urban and rural areas, between regions, there is a big economic development imbalances. Due to the constraints of the economic strength of the current university teaching management information level of imbalance in economic development, the process of information more slowly[4].

Teaching Management IT application level is uneven, the overall low level. Teaching computer application level management personnel and other modern management tools is uneven, is to achieve a low overall level of teaching management information a constraining factor.

Lack of quality for teaching management software. Can not be denied, the university teaching management application software development and various software vendors, and high quality for much Currently, most of this or that problem more or less. Some software is also a lack of security, prone to data or information / stolen or compromised 0 . Lack of quality for teaching management software to some extent, also influenced the teaching process of the implementation of management information.

\section{MEASURES}

Changes in teaching philosophy, creating teaching management information environment. First, to change teachers' ideas for teachers to recognize the use of modern information science and technology major changes to the teaching mode, teaching methods. Second, leaders must increase the degree of attention, and establish the concept of teaching management information, the information technology as a key teaching management, the establishment of monitoring and inspection mechanisms to ensure the teaching of the normal operation of management information. Teaching management in the key lies in the application of information technology, school staff and students to actively participate in teaching the use of management information systems. Universities in teaching management information construction process, there must be conscious that everyone wants to create, everyone will use the information environment.

Strengthen teaching management ranks. With the accelerated process of university teaching management information, improving information literacy and information management capabilities of teaching management is a necessary requirement to adapt to the development of the level of quality and strength of their ability to directly determine the effectiveness of teaching management and information construction . Emphasis on efforts to strengthen the school, there are plans to organize teaching administrators and staff training, such as through a number of incentives to encourage staff to improve the teaching management level of computer applications, excluding technical and operational obstacles[5].

Establish scientific teaching management information systems. Construction teaching management information system related to information technology and information resources in two ways. In information technology, design and development of teaching management information systems to fit the school 's own characteristics, in order to better used in teaching management, improve management efficiency. During development of information systems, the responsible person must be involved in decision-making role play, thus providing strong guidance and support for the design of teaching management information systems. In the system put into use, have specialized personnel to monitor the system at any time to improve and perfect the system according to the specific requirements to improve the usability of the system. Information resources, development and construction of information resources is teaching core content management information, including student information, teacher information, course information, teaching condition information, education news and 
information . Development and construction of information resources must be based on modern education as guidance to ensure that scientific and normative data,

Formulate rules and regulations relating to the management of information technology in teaching. Teaching management information construction involves not only the concept of change, supporting the management team to improve the level of capital investment , technology, and education also need to establish a management information management system to adapt . Colleges and universities according to their actual situation , formulate relevant rules and regulations of teaching management, information technology, and to focus on the systemic system operability, supervisory, teaching management to ensure standardization of procedures for implementation. In the implementation process, not a mere formality, to do with the standard management system, using modern means to ensure that the management, In order to improve the efficiency and quality of management.

\section{REFERENCES}

[1]Jiang Dongxing.Current Situation of the Development of Information Technology Analysis and Policy Advice [J]. Chinese Education Info, 2009: (15).

[2]Gao Fucheng. On the Construction of Teaching Management Informatization in the Colleges and Universities [J]. Theory and Practice of Education,2011:23-25.

[3]Jiang Jie. Problems of Teaching Information Tchnology Management and Strategy Analysis [J]. Journal of Teaching and Management,2008(12):26-27.

[4]Lin Xurun, Sun Xiaohua.Exploration and Practice of Teaching Management Information Construction Vocational [J]. China Education Network, 2013(7):35-36.

[5]Li Hongmei, Zhang Sufen, Liu Yanjuan. Thinking and Exploration of Teaching Management Information Construction[J]. Higher Agricultural Education, 2011(2):45-47. 